\title{
Alcaligenes faecalis subsp. homari subsp. nov., a New Group of Bacteria Isolated from Moribund Lobsters
}

\author{
B. AUSTIN, ${ }^{1}$ C. J. RODGERS, ${ }^{1}$ J. M. FORNS, ${ }^{2}$ AND R. R. COLWELL ${ }^{3}$ \\ Ministry of Agriculture, Fisheries and Food, Fish Diseases Laboratory, The Nothe, Weymouth, Dorset, DT4 \\ 8UB, England ${ }^{1}$; Applied Marine Ecology Laboratory, Falmouth, Massachusetts 02540 ${ }^{2}$; and Department of \\ Microbiology, University of Maryland, College Park, Maryland $20742^{3}$
}

\begin{abstract}
Eight strains isolated from the hemolymph of moribund lobsters were classified in a new subspecies of Alcaligenes faecalis on the basis of a study of their phenotypic characteristics. The name Alcaligenes faecalis subsp. homari is proposed for this new subspecies, of which the type strain is L1 (= NCMB 2116 $=$ ATCC 33127).
\end{abstract}

Bacterial diseases of lobsters include gaffkemia, shell disease, and larval asphyxiation, which are caused by "Aerococcus viridans subsp. homari" (19), unidentified gram-negative, chitinolytic bacteria (15), and Leucothrix mucor (18), respectively. However, bacterial isolates distinct from these organisms were recovered in pure culture from the hemolymph of moribund lobsters (Homarus americanus) during 1978. They were phenotypically dissimilar to all of the recognized fish and crustacean pathogens $(15,18-$ 20 ), and from a detailed taxonomic study, it was shown that the isolates were members of Alcaligenes faecalis. In fact, it is proposed that the organisms constitute a new subspecies, Alcaligenes faecalis subsp. homari.

\section{MATERIALS AND METHODS}

Lobsters. Lobsters ( $H$. americanus) were reared at Martha's Vineyard, Mass., individually in tanks containing seawater at a salinity of ca. 30 to $33 \%$. The temperatures of the water in the tanks varied from $-1^{\circ} \mathrm{C}$ in winter to $23^{\circ} \mathrm{C}$ in summer. Feeding, with frozen brine shrimp (Artemia salina), was undertaken twice daily.

For 3 days in August 1977, the water temperature exceeded $26^{\circ} \mathrm{C}$, and shortly afterwards, after the onset of molting, $18 \%$ of the 1-year-old lobsters died. The only external symptoms included the presence of softened shells and occasional opaque areas approximately $5 \mathrm{~mm}$ in diameter on the carapace. Postmortem examinations were carried out on moribund and dead animals.

Bacterial strains. Eight bacterial strains, designated L1 through L8, were isolated from the hemolymph of eight moribund lobsters. Drops of hemolymph, collected aseptically, were inoculated onto plates of Marine Agar 2216E (Difco Laboratories), and after incubation at $19^{\circ} \mathrm{C}$ for 7 days, single-culture growth was observed. The isolates were streaked onto plates of $2216 \mathrm{E}$ agar, with three serial streakings of each culture made to ensure purity. After purification, cultures were inoculated onto $2216 \mathrm{E}$ agar slants and maintained at $4^{\circ} \mathrm{C}$. Subculturing was done every 6 to
8 weeks. The strains were compared with nine marker strains, including Acinetobacter calcoaceticus ATCC 15308, Aeromonas hydrophila ATCC 9071, Aeromonas salmonicida ATCC 14174, Alcaligenes faecalis NCTC 655 (= FP/63/78, a laboratory strain), Enterobacter aerogenes NCTC 8172, Escherichia coli NCTC 8136, Vibrio anguillarum NCMB 1875, and Vibrio parahaemolyticus NCTC 10441.

Characterization of the strains. The strains were examined by 107 tests described previously for use in numerical taxonomy studies (2) and by 17 antibiotic susceptibility tests detailed below. Unless otherwise stated, marine agar $2216 \mathrm{E}$ was used as the basal medium, and inoculated media were incubated at $19^{\circ} \mathrm{C}$ for 14 days before the results were recorded.

Antibiotic susceptibility. Susceptibilities to ampicillin $(10 \mu \mathrm{g})$, chloramphenicol $(10 \mu \mathrm{g})$, chlortetracycline $(10 \mu \mathrm{g})$, cloxacillin $(5 \mu \mathrm{g})$, colistin sulfate $(10$ $\mu \mathrm{g})$, erythromycin $(10 \mu \mathrm{g})$, furazolidone $(50 \mu \mathrm{g})$, gentamicin $(10 \mu \mathrm{g})$, kanamycin $(30 \mu \mathrm{g})$, neomycin $(10 \mu \mathrm{g})$, nitrofurantoin $(200 \mu \mathrm{g})$, novobiocin $(5 \mu \mathrm{g})$, penicillin $\mathrm{G}$ $(1.5 \mathrm{U})$, streptomycin $(10 \mu \mathrm{g})$, sulfamethoxazole (25 $\mu \mathrm{g})$, sulfafurazole $(500 \mu \mathrm{g})$, and tetracycline $(50 \mu \mathrm{g})$ were determined by the method of Allen et al. (1). In addition to marine agar $2216 \mathrm{E}$, tryptone soya agar (Oxoid) was used in determining antibiotic susceptibility. Zones of clearing around the antibiotic disks were measured as soon as growth could be detected, i.e., $24 \mathrm{~h}$ at $19^{\circ} \mathrm{C}$.

Determination of the deoxyribonucleic acid base composition. The quanine-plus-cytosine content of purified deoxyribonucleic acid, prepared by the method of Marmur (11), was calculated from the thermal denaturation temperature, $T_{m}$ (12), according to the equation of De Ley (5).

Electron microscopy. Strain L1, grown for $24 \mathrm{~h}$ at $19^{\circ} \mathrm{C}$ on marine agar $2216 \mathrm{E}$, was suspended in $0.9 \%$ (wt/vol) saline to ca. $10^{9}$ cells per $\mathrm{ml}$, negatively stained with $2 \%(\mathrm{wt} / \mathrm{vol})$ uranyl acetate, and examined with a JEOL $100 \mathrm{CX}$ transmission electron microscope.

Pathogenicity. Suspensions of L1, NCTC 655, and FP/63/78, washed three times in $0.9 \%$ (wt/vol) saline and suspended to ca. $10^{7}$ cells per ml, were injected (1$\mathrm{ml}$ volumes) into the heart of each of three $1 \mathrm{-kg}$ European lobsters ( $H$. vulgaris). Additional lobsters, 
serving as controls, were each injected with $1 \mathrm{ml}$ of $0.9 \%$ (wt/vol) saline. The lobsters were kept in separate 50 -liter fiber glass tanks which received a constant flow of oxygenated seawater (20 liters/h) maintained at $9^{\circ} \mathrm{C}$. Observations were made daily, and moribund or dead lobsters were removed for postmortem examination. Hemolymph and tissue from the heart, spleen, liver, and abdominal muscle were collected aseptically and were subjected to bacteriological and histopathological examination.

Computer analyses. The 17 strains were examined for 124 unit characters coded in binary format by scoring positive, negative, and noncompatible results as 1,0 , and 9 , respectively. Similarities between strains were calculated by using the simple matching ( $S_{S M}$; 17) and Jaccard $\left(S_{J} ; 16\right)$ coefficients, and sorted similarity matrices and dendrograms were obtained by use of the unweighted average-linkage algorithm (17).

Identification of lobster isolates. The diagnostic criteria of Hendrie et al. (6) and Holding and Shewan (7) were consulted in identifying the isolates.

\section{RESULTS}

Examination of results of computer analyses. The numerical classifications obtained with the $S_{S M}$ and $S_{J}$ coefficients were almost identical, and only the one based on the $S_{J}$ coefficient is considered further. One cluster and seven single-member clusters were defined at the $85 \%$ similarity level (Fig. 1). The eight bacterial isolates from moribund lobsters clustered together in a single, well-defined group at the $90 \%$ similarity level (Fig. 1). This cluster joined with the two marker strains of $A$. faecalis at the $85 \%$ similarity level.

Characteristics of the lobster isolates. The eight strains isolated from lobsters each consisted of gram-negative, straight or curved, peritrichous rods (Fig. 2), ca. $1.5 \mu \mathrm{m}$ in length, with rounded ends and bipolar staining reactions; they produced off-white, translucent, raised, smooth colonies, 2 to $3 \mathrm{~mm}$ in diameter, on marine agar $2216 \mathrm{E}$ within $24 \mathrm{~h}$ at $37^{\circ} \mathrm{C}$. The results of the remaining tests performed on these isolates are shown in Table 1.

The isolates possess the characteristics of the genus Alcaligenes insofar as they are gram-negative, motile, peritrichous (three to eight flagella), oxidase-positive, coccal rods which produce an alkaline reaction in glucose $(5-7,14)$. They matched the general description of $A$. faecalis (5-7), viz., utilization of carbon compounds, including sodium acetate, as the sole source of carbon for energy and growth at $37^{\circ} \mathrm{C}(6,7)$. However, a number of characteristics differentiated them from $A$. faecalis, and these are summarized in Table 2.

Pathogenicity. Lobsters injected with a suspension of $\mathrm{L} 1$ died within 7 days. After bacteriological and histopathological examinations, the hemolymph and spleen were found to be packed with bacterial cells which possessed the characteristics of L1. In contrast, lobsters inoculated with suspensions of $A$. faecalis NCTC 655 (=

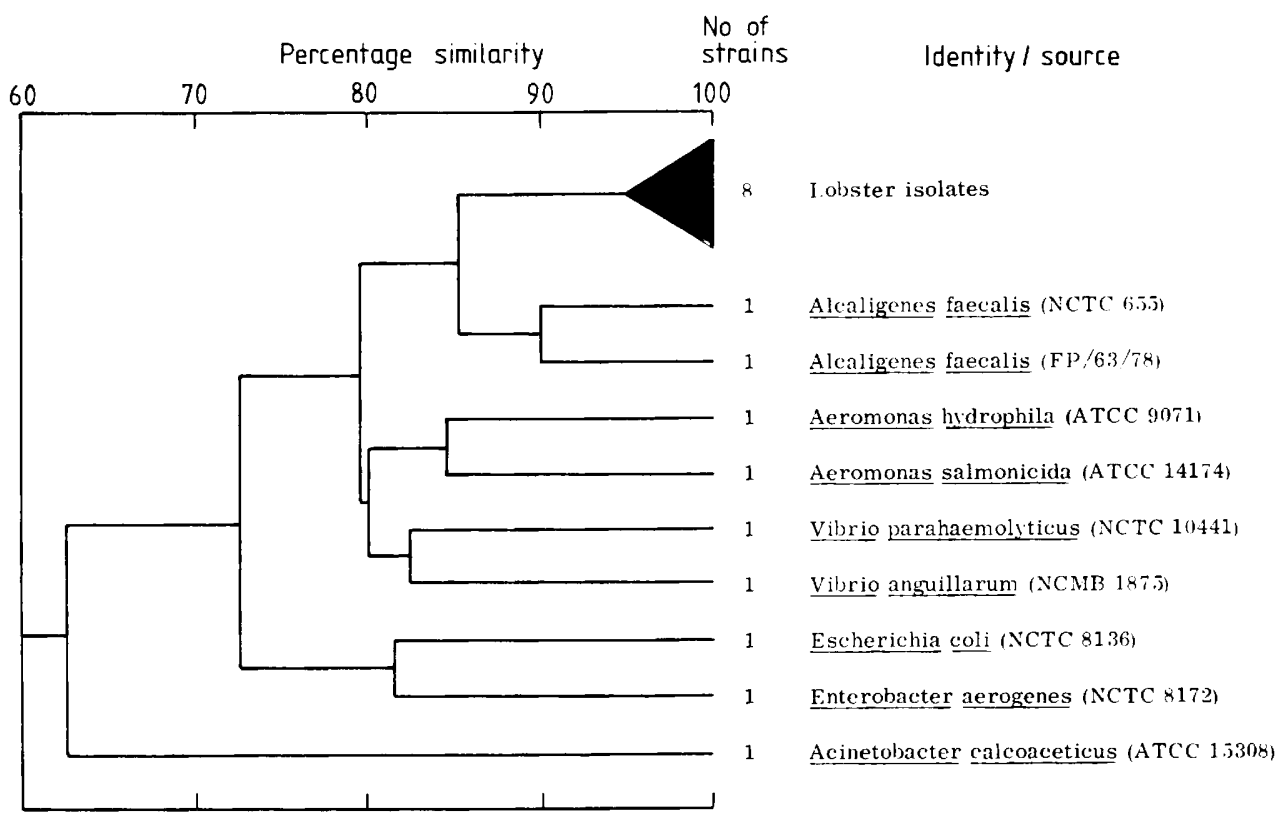

Fig. 1. Simplified dendrogram based on the $S_{J}$ coefficient and unweighted average-linkage clustering algorithm. 


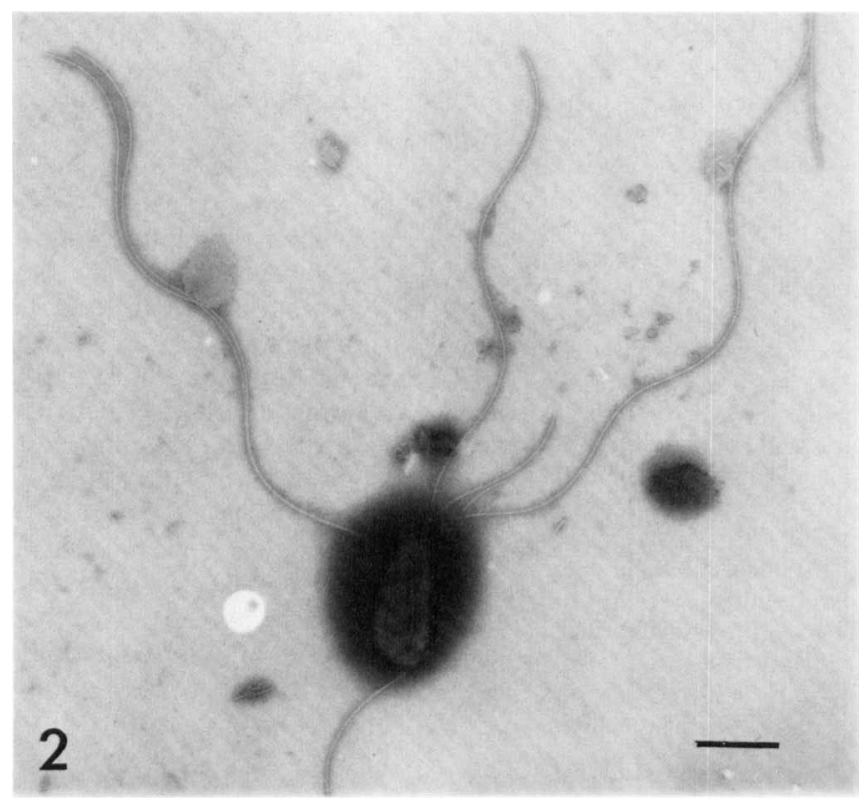

FIG. 2. Negatively stained preparation of L1 showing peritrichous cell with seven flagella. Bar, $1 \mu$ m.

TABLE 1. Phenotypic characteristics of A. faecalis subsp. homari subsp. nov. and its type strain L1 (= NCMB 2116 = ATCC 33127)

\begin{tabular}{|c|c|c|c|}
\hline Characteristic & Reaction & Characteristic & Reaction \\
\hline Peritrichous & + & Blood & - \\
\hline Strictly aerobic & + & Casein & - \\
\hline Nitrate reduction & + & $\ldots \ldots \ldots$ & - \\
\hline Growth at $4-42^{\circ} \mathrm{C}$ & + & Gelatin . & - \\
\hline Growth in $1-10 \%$ (wt/vol) $\mathrm{NaCl} \ldots \ldots \ldots$ & + & Tweens $5,20,40,60$, and 80 & - \\
\hline Susceptible to: & & Tyrosine $\ldots \ldots \ldots \ldots \ldots \ldots \ldots$ & - \\
\hline Ampicillin . & + & Xanthine & - \\
\hline Chloramphenicol & + & Utilization of: & \\
\hline Furazolidone $\ldots \ldots \ldots \ldots \ldots \ldots$ & + & DL- $\alpha$-Alanine & + \\
\hline Gentamicin $\ldots \ldots \ldots \ldots \ldots$ & + & D (+)-Cellobiose $\ldots \ldots \ldots \ldots \ldots \ldots$ & + \\
\hline$\ldots \ldots \ldots \ldots$ & + & meso-Erythritol . . . . . . . . . . . & + \\
\hline$\ldots \ldots \ldots \ldots$ & + & D (-)-Fructose $\ldots \ldots$ & + \\
\hline Sulfafurazole & + & D (-)-Galactose & + \\
\hline Chlortetracycline & - & Inulin $\ldots \ldots \ldots \ldots \ldots \ldots \ldots$ & + \\
\hline Cloxacillin ...... & - & $\ldots \ldots \ldots \ldots \ldots$ & + \\
\hline Coliston sulfate & - & $\ldots \ldots \ldots \ldots \ldots$ & + \\
\hline Erythromycin . & - & D (+)-Melezitose $\ldots \ldots \ldots \ldots \ldots \ldots$ & + \\
\hline Nitrofurantoin $\ldots \ldots \ldots \ldots \ldots$ & - & L-Proline $\ldots \ldots \ldots$ & + \\
\hline Neomycin $\ldots \ldots \ldots \ldots \ldots$ & - & $\mathrm{L}(+)$-Raffinose $\ldots \ldots \ldots \ldots$ & + \\
\hline Novobiocin & - & L (+)-Rhamnose $\ldots \ldots \ldots \ldots$ & + \\
\hline Streptomycin & - & L-Serine $\ldots \ldots \ldots$ & + \\
\hline Sulfamethoxazole & - & Sodium acetate & + \\
\hline Tetracycline ......... & - & Sodium citrate $\ldots \ldots \ldots$ & + \\
\hline Ornithine decarboxylated & + & Sodium glutamate $\ldots \ldots \ldots \ldots \ldots$ & + \\
\hline Production of: & & Sodium malonate $\ldots \ldots \ldots \ldots \ldots$ & + \\
\hline Catalase ... & + & Sorbitol $\ldots \ldots \ldots \ldots \ldots \ldots$ & + \\
\hline Oxidase & + & $\ldots \ldots \ldots \ldots$ & + \\
\hline $\mathrm{H}_{2} \mathrm{~S}$ (slowly) & + & D (+)-Trehalose $\ldots \ldots \ldots \ldots \ldots \ldots$ & + \\
\hline Fluorescent pigments & - & Dulcitol $\ldots \ldots \ldots \ldots \ldots \ldots \ldots \ldots$ & - \\
\hline Indole $\ldots \ldots \ldots \ldots$ & - & $\ldots \ldots \ldots \ldots \ldots \ldots$ & - \\
\hline Levan & - & Sodium formate ...... & - \\
\hline Phenylalanine deaminase & - & D (+)-Xylose $\ldots \ldots \ldots \ldots \ldots \ldots$ & - \\
\hline Hydrolysis of: & & Arginine dihydrolase $\ldots \ldots \ldots \ldots \ldots$ & - \\
\hline Starch (slowly) & + & Methyl red test ... & - \\
\hline Urea ........ & + & Voges-Proskauer reaction $\ldots \ldots \ldots$ & - \\
\hline$\ldots \ldots \ldots \ldots$ & - & & \\
\hline
\end{tabular}


TABLE 2. Differentiation of lobster isolates from $A$. faecalis

\begin{tabular}{lcc}
\hline \multicolumn{1}{c}{ Character } & $\begin{array}{c}\text { Lobster } \\
\text { isolates }\end{array}$ & A. faecalis \\
\hline $\begin{array}{c}\text { Granular cytoplasm } \\
\text { (bipolar staining) }\end{array}$ & + & - \\
Ornithine decarboxylase & + & - \\
Starch hydrolysis (slow) & + & - \\
Growth in: & - & + \\
$0 \%$ (wt/vol) NaCl & + & - \\
$10 \%$ (wt/vol) NaCl & + & - \\
Pathogenic for lobsters & + & \\
\hline
\end{tabular}

FP/63/78) remained healthy up to the close of the experiment at 12 weeks. Bacteriological and histopathological examination failed to show any evidence for the presence of microorganisms in the hemolymph, spleen, or any other organ of these animals.

\section{DISCUSSION}

Alcaligenes spp. have not previously been considered as shellfish pathogens $(8,10)$, and therefore it is interesting that strains with the characteristics of $A$. faecalis should be recovered from the hemolymph of moribund lobsters. This isolation is especially significant because bacteria are usually cleared rapidly from the hemolymph $(4,13)$. However, Alcaligenes strains are not uncommon to the marine environment, as ZoBell and Upham (20) and Baumann et al. (3) have described several new species to accommodate marine strains. Additional species accommodate soil strains (7).

Although the description of the lobster isolates closely matched that of A. faecalis $(6,7$, 14), there were some important differences, notably in colonial and micromorphology, starch hydrolysis, ornithine decarboxylase production, and growth in 1 to $10 \%(\mathrm{wt} / \mathrm{vol}) \mathrm{NaCl}$. Moreover, the guanine-plus-cytosine content of the deoxyribonucleic acid of these strains $(56.6 \mathrm{~mol} \%)$ is lower than the generally accepted value for $A$. faecalis of $58.9 \mathrm{~mol} \%(6,7)$. However, this lower value is identical to the guanine-plus-cytosine content of "A. odorans" (9; not on the Approved Lists of Bacterial Names [Int. J. Syst. Bacteriol. 30:225-420, 1980]), which has been regarded as an objective symonym of $A$. faecalis (6).

For these reasons, it is proposed that the lobster isolates be classified as a new subspecies of A. faecalis, A. faecalis subsp. homari subsp. nov. (M.L. noun Homarus generic name of the lobster; M.L. gen. noun homari of the lobster). A description of the subspecies follows.

Alcaligenes faecalis subsp. homari subsp. nov.
Gram-negative, motile, peritrichous (three to eight flagella; Fig. 2), straight or curved rods, ca. $1.5 \mu \mathrm{m}$ in length. Bipolar staining reactions are evident.

Colonies on $2216 \mathrm{E}$ agar are off-white, translucent, raised, smooth, 2 to $3 \mathrm{~mm}$ in diameter after $24 \mathrm{~h}$ at 19 and $37^{\circ} \mathrm{C}$, and with a slight tendency to spread. Fluorescent, diffusible pigments are not produced.

Broth cultures are uniformly turbid.

Chemoorganotrophic; metabolism is strictly respiratory. Alkali is produced from glucose metabolism.

Nitrates are reduced to nitrites.

Grows at 4 to $42^{\circ} \mathrm{C}, \mathrm{pH} 5$ to 9 , and in 1 to $10 \%$ (wt/vol) $\mathrm{NaCl}$.

Susceptible to ampicillin, chloramphenicol, furazolidone, gentamicin, kanamycin, penicillin $\mathrm{G}$, and sulfafurazole.

Catalase and oxidase are produced.

Ornithine is decarboxylated.

Starch and urea are slowly decomposed, but not esculin, blood, casein, chitin, gelatin, Tweens $5,20,40,60$, and 80 , tyrosine, and xanthine.

$\mathrm{H}_{2} \mathrm{~S}$ is slowly produced, but not indole, levan, or phenylalanine deaminase.

The methyl red test and Voges-Proskauer reactions are negative.

Utilizes DL- $\alpha$-alanine, D-(+)-cellobiose, mesoerythritol, D-(-)-fructose, D-(-)-galactose, inulin, lactose, maltose, D-(+)-melezitose, L-proline, L-(+)-raffinose, L-(+)rhamnose, L-serine, sodium acetate, sodium citrate, sodium glutamate, sodium malonate, sorbitol, sucrose, and D-(+)-trehalose, but not dulcitol, L-glycine, sodium formate, or D-(+)-xylose as the sole source of carbon for energy and growth.

Deoxyribonucleic acid base composition: 56.6 $\pm 0.5 \mathrm{~mol} \%$ guanine plus cytosine.

Type strain: L1, a culture of this strain has been deposited with the National Collection of Marine Bacteria, Aberdeen, Scotland, as NCMB 2116, and with the American Type Culture Collection, Rockville, Md., as ATCC 33127.

\section{ACKNOWLEDGMENTS}

We thank M. S. Hendrie for helpful discussion. The electron micrograph was provided by D. J. Alderman.

\section{REPRINT REQUESTS}

Address reprint requests to: Dr. B. Austin, Ministry of Agriculture, Fisheries and Food, Fish Diseases Laboratory, The Nothe, Weymouth, Dorset DT4 8UB, England.

\section{LITERATURE CITED}

1. Allen, D. A., B. Austin, and R. R. Colwell. 1977 Antibiotic resistance patterns of metal-tolerant bacteria isolated from an estuary. Antimicrob. Agents Chemother. 12:545-547.

2. Austin, B., D. A. Allen, A. Zachary, M. R. Belas, and 
R. R. Colwell. 1979. Ecology and taxonomy of bacteria attaching to wood surfaces in a tropical harbor. Can. J. Microbiol. 25:447-461.

3. Baumann, L., P. Baumann, M. Mandel, and R. D. Allen. 1972. Taxonomy of aerobic marine eubacteria. J. Bacteriol. 110:402-429.

4. Cornick, J. W., and J. E. Stewart. 1968. Interaction of the pathogen Gaffkya homari with natural defense mechanisms of Homarus americanus. J. Fish. Res. Board Can. 25:695-709.

5. De Ley, J. 1970. Reexamination of the association be tween melting point, buoyant density, and chemical base composition of deoxyribonucleic acid. J. Bacteriol. 101:738-754.

6. Hendrie, M. S., A. J. Holding, and J. M. Shewan. 1974. Emended descriptions of the genus Alcaligenes and of Alcaligenes faecalis and proposal that the generic name Achromobacter be rejected: status of the named species of Alcaligenes and Achromobacter. Int. J. Syst. Bacteriol. 24:534-550.

7. Holding, A. J., and J. M. Shewan. 1974. Genus Alcaligenes Castellani and Chalmers 1919, 936, p. 273-275. In R. E. Buchanan and N. E. Gibbons (ed.), Bergey's manual of determinative bacteriology, 8 th ed. The Williams \& Wilkins Co., Baltimore.

8. Leibovitz, L. 1978. Shellfish diseases. Mar. Fish. Rev. 40: 61-64.

9. Malek, I., and V. Kadzová-Kožiškova. 1946. Pseudomonas adorans n. sp. Nov. Mikrob. z. Diagnostic. Materialu. Sb. Lek. 47:189-194.

10. Malloy, S. C. 1978. Bacteria induced shell diseases of lobsters (Homarus americanus). J. Wildl. Dis. 14:2-10.
11. Marmur, J. 1961. A procedure for the isolation of deoxyribonucleic acid from micro-organisms. J. Mol. Biol. 3: 208-218.

12. Marmur, J., and P. Doty. 1962. Determination of the base composition of deoxyribonucleic acid from its thermal denaturation temperature. J. Mol. Biol. 5:109-118.

13. Mori, K., and J. E. Stewart. 1978. The hemolymph bactericidin of American lobster (Homarus americanus): adsorption and activation. J. Fish. Res. Board Can. 35:1504-1507.

14. Pichinoty, F., M. Véron, M. Mandel, M. Durand, C. Job, and J.-L. Garcia. 1978. Physiological and taxonomic study of the genus Alcaligenes: $A$. denitrificans, A. odorans and A. faecalis. Can. J. Microbiol. 24:743753.

15. Rosen, B. 1970. Shell diseases of aquatic crustaceans. Am. Fish. Soc. Spec. Publ, 5:409-415.

16. Sneath, P. H. A. 1957. The application of computers to taxonomy. J. Gen. Microbiol. 17:201-226.

17. Sokal, R. R., and C. D. Michener. 1958. A statistical method for evaluating systematic relationships. Univ. Kans. Sci. Bull. 38:1409-1438.

18. Steenbergen, J. F., and H. C. Schapiro. 1974. Gaffkemia in California spiny lobsters. Proc. World Mariculture Soc. 5:139-143.

19. Stewart, J. E., and B. M. Swicker. 1974. Comparison of various vaccines for inducing resistance in the lobster Homarus americanus to the bacterial infection, gaffkemia. J. Fish. Res. Board Can. 31:1887-1892.

20. ZoBell, C. E., and H. C. Upham. 1944. A list of marine bacteria including descriptions of sixty new species. Bull. Scripps Inst. Oceanogr. 5:239-292. 